\title{
The Analysis of Scientific Guidance Academic Procrastination
}

\author{
Muljono Damopolii, ${ }^{1 *}$, M. Yusuf T. ${ }^{2}$, Muhammad Shabir U. ${ }^{3}$, Kamsinah $^{4}$ \\ ${ }^{1}$ Department of Islamic Education, Faculty of Tarbiyah and Teacher Training, Universitas Islam Negeri Alauddin Makassar, Indonesia \\ ${ }^{2}$ Department of Early Childhood Islamic Education, Faculty of Tarbiyah and Teacher Training, Universitas Islam Negeri Alauddin \\ Makassar, Indonesia \\ ${ }^{3}$ Department of Islamic Elementary Education, Faculty of Tarbiyah and Teacher Training, Universitas Islam Negeri Alauddin Makassar, \\ Indonesia \\ ${ }^{4}$ Department of English Education, Faculty of Tarbiyah and Teacher Training, Universitas Islam Negeri Alauddin Makassar, Indonesia
}

Received August 12, 2020; Revised November 4, 2020; Accepted November 11, 2020

\section{Cite This Paper in the following Citation Styles}

(a): [1] Muljono Damopolii, M. Yusuf T., Muhammad Shabir U., Kamsinah, "The Analysis of Scientific Guidance Academic Procrastination," Universal Journal of Educational Research, Vol. 8, No. 12, pp. 7078 - 7084, 2020. DOI: 10.13189/ujer.2020.081275.

(b): Muljono Damopolii, M. Yusuf T., Muhammad Shabir U., Kamsinah (2020). The Analysis of Scientific Guidance Academic Procrastination. Universal Journal of Educational Research, 8(12), 7078 - $7084 . \quad$ DOI: 10.13189/ujer.2020.081275.

Copyright $\bigcirc 2020$ by authors, all rights reserved. Authors agree that this article remains permanently open access under the terms of the Creative Commons Attribution License 4.0 International License

\begin{abstract}
Guiding involves verbal communication interactions and engages in complex cognitive aspects. The cognitive deviation between individuals during the guidance process of writing academic papers is a determining factor as well as differentiates the results of guiding. This study aimed to study the effects of academic procrastination on the scientific guidance process at the Postgraduate Program of UIN Alauddin Makassar. This study used quantitative and qualitative methods. Descriptive statistics were employed to analyze the quantitative data, and the descriptive qualitative data were analyzed using a responsive evaluation model developed by Robert Stake, which covered three main phases; antecedents, transactions, and outcomes. The research instruments were questionnaire and interview. The questionnaire used three aspects of procrastination standardized by Tuckman. Those three aspects were developed into 35 items of procrastination statements with answer choices using the Five-Point of Likert Scale; always, often, sometimes, rarely, and never. While semi structured-interview was used to gain additional data related to the students' writing academic guidance process. The research finding indicated that the academic procrastination on academic guidance was moderate so that the quality of students' academic works was relatively low. Therefore, The students' academic procrastination
\end{abstract}

and the imperfect formal flow of guidance affect academic guidance process not run optimally. This study recommends that Postgraduate UIN Alauddin Makassar should compile guidelines for the writing of scientific papers that are applied exclusively to the needs of the guidance and reporting of scientific papers.

Keywords Procrastination, Scientific Guidance, Student's Academic Work

\section{Introduction}

Supervision of academic scientific work is one of the primary roles of lecturers' functional position, teaching, and research. This role is relatively mutual because the supervisor and the supervisee are actively involved in processing a complete set of studies with various components.

Guiding does not only involve verbal communication interactions but also engages in complex cognitive aspects. The cognitive deviation between individuals during the process is a determining factor as well as differentiating the results of guiding.

Complex cognition can be understood as a mental 
structure that influences perception. Symptoms are often found in the supervisor who complained about the guided subject's weakness in developing the results of their communication into the report structure, which is the output of the guiding activity. It reveals that the complexity of interactions in communication guiding requires more actions than just meeting and talking, namely through intensive communication. Learning science is called learning communication.

Learning communication essentially emphasizes the objects that have been studied and not on what has been previously known [1]. It means that the decision chosen should base on the object of communication and how the purpose is communicated. In the context of supervising, these objects can be skills and knowledge of new situations, work designs, including non-routine work activities, innovation, and other effective personal qualities that will further shape inter-personal competence. Competence is the basic ability needed to optimize guiding. The parties in the guiding process also need social expertise as well as cognitive capability. Social competence is essentially a concept whose meaning is broader than mere knowledge, skills, and values [2]. This competency is related to the ability to develop soft skills, especially in personal communication skills such as sympathy, empathy, and so on.

In the practice of guiding, it was found various problems because of the inability of two or one parties to develop the skills. Occasionally a preceptor accuses his/her supervisee (students) works out of instructions, and vice versa; the student does not claim to get meaningful guidance from his/her supervisor. This problem has long been a theme studied by experts such as social learning theorists and social hermeneutics scientists.

The researchers study the aspects that become bottlenecks in the management of scientific work guidance by referring to previous ideas. The element is often ignored even though it is an important point that needs to be examined so that the operational guidance system can run as expected while recommending the design of a guiding process based on the self-based analysis. This basis is considered strategic because guiding involves the interaction of self-interest as a personal basis, which influences someone in deciding to choose or reject an object.

Procrastination is one of the self-interest study concepts and an emotional phenomenon existing in every human being. It is gifted to varying degrees in each person. Etymologically, procrastination is formed from two Latin words, pro and crastinus. Pro means forward and crastinus, which means tomorrow [3]. The concept of it is derived from those two series of words, which is the mental attitude that should put something to do soon (pro) but done later (crastinus). Procrastination or delaying can be related to anxiety and fear of failure [4].
Generally, procrastination is defined as a mechanism to deal with anxiety (coping with) associated with the beginning or completion of any task or decision [5]. Moreover, it is synonymous with procrastinating, lazy, or ignorant of something, which is conceptually different because of its distinctive quality. Laziness, for example, means false decisions, while procrastination does not necessarily contain that meaning.

Some experts believe that procrastination can be developed into a mental model that effectively addresses individual problems. Overcoming procrastination is the art of making something more than it should be until something is more meaningful than its needs (the art of making something into more than it is until it expands into more than it needs to be) [3]. Delays that are not accompanied by an adaptive role can cause experience procrastination to underachieve [6].

There are two basic characteristics to define procrastination [7], namely: (1) delayable, and (2) important task. Delayable or capable of being delay, is a mental model of individuals who easily find reasons not to do things when they should. Meanwhile, the important task or urgent duty is the work object that should receive priority completion.

Regarding these two characteristics, the concept of procrastination does not cover all forms of personality disorder but is attached to a delay due to a motive [8]. The motivation of procrastination can be internal such as feeling satisfied, happy, comfortable, or interested, and can also be existed from external stimulation such as attraction. This statement is in line with Schouwenburg in Mierrina that a procrastinator made a delay that led to a pleasant choice [9]. Besides, procrastination might be a challenging and an entrenched issue, which may require further attention and psychological intervention [10].

The procrastination in a person is characterized by six common characteristics [5], namely: (1) Feeling of having a long time to complete an obligation; (2) Being not realistic in determining the time; (3) Being difficult to set goals or value standards; (4) Filled with insufficient feelings, frustration or depression; (5) Filled with doubt and fear to make mistakes; and (6) Having low self-esteem and less assertive of work productivity.

The six general characteristics above are not always attached to a procrastinator. Still, if one or several of them have a phenomenon towards someone, it will show the category of procrastination problems against him/her. If someone is asked: "why isn't the task done?" then he answers, "I am lazy,” or "I am ashamed," or "I am afraid of being wrong," indicating that the person is in the category of lazy procrastination, ashamed or afraid of being wrong. They might find the task difficult and unpleasant. Some people do procrastination because they see the task as something heavy and uncomfortable [11].

Personality itself is a unique dynamic organization found in individuals that is a psychophysical system 
determining the individual's unique way of adjusting to the environment [12]. It is called as typical because the personality has a different structure between one person to another. Two people who are identified as having the same personality are not necessarily the same because of various emotional responses. Based on the results of research conducted by McRae, Ochner, \& Gross, emotions, both biologically and sociologically, can be used to overcome various problems and or identify opportunities in dynamic ways (involving changes) through various responses networks [13]. The following is the description of the emotion mechanism called the emotion modal-model as follows: [13].

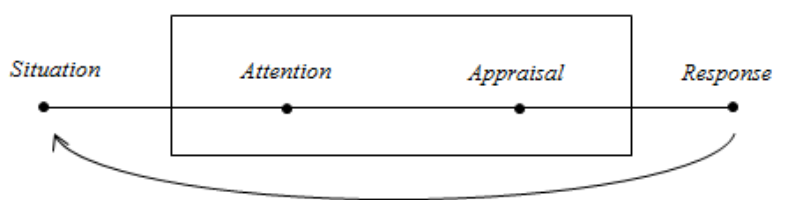

Figure 1. Job Description of Emotion Modal-Model

Figure 1 explains the general emotional process of work. Emotion is essentially a process of individual response to various stimulants that shape emotional situations. The emotional model is not necessarily formed by a linear response but is influenced by appraisal (a source or object) and attention (heed).

An appraisal is a source or object that influences cognitive assessment, which generally comes from subjective experience and commonly shapes individual perception. Personal experience (subjective perspective) itself can be affirmed to the closeness or familiarity of the individual (previous exposure) in recognizing the surrounding objects, either real or abstract.

These objects also affect individuals' attention and are even relatively chosen as a result of subjective judgments explained previously. In contrast, care is a symptom of behaviour as well as a cognitive work process. The process of cognitive work from the beginning has been an important theme in psychology, especially in maintaining the substantive meaning called "to know," "to understand," and the mental processes resulted. It is in line with what is explained by the cognitivist that the process of cognition takes place in general sequence, as seen in Figure 2 as follows: [14].

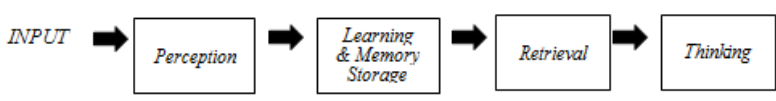

Figure 2. Description of Cognition Work Process Stages

Figure 2 explains that human cognition works beginning with receiving input. The input is then perceived, studied so that a learning process occurs with the results stored in the memory system. The input itself is in the form of information that has been extracted in such a way that individuals can perceive it. Perception is the process of interpreting data so that it can be used in learning (input received), the results of which are stored in the memory system. The memory system is the large storage that saves a lot of information that can be reused (retrieval) if needed. Information is also a common basis for human thought activities.

The comparison between Figure 1 and Figure 2 emphasizes that individuals' emotional situation is different due to the various distinctive inputs that are responded differently by each individual. The intensity of the response also affects the modulation of values so that it has the potential to influence perception. Thus, changes in perception are principally cognitive changes that are shifted due to changes in objects' input value.

Cognitive changes in various forms constitute the attentional deployment. In contrast, to focus, attention is formed by a variety of complex and relevant devices. Hence the more complex a person's attention, the more complex he/she can modify the situation and or choose a position that suits his/her condition.

In connection with procrastination, delaying, or doing is an emotional situation that is modified internally by the individual. This symptom can be observed from the delay symptoms, which always have a reason. The other symptoms that are the same have the same indication, laziness, for instance. Someone's laziness is still based on certain and specific reasons, so laziness itself is a symptom that has been modified or may be chosen because of the relevant situation.

In terms of another emotional processing (emotional regulation), the procrastination process can also be described in the same way that the pattern can be seen in Figure 3. It illustrates more clearly how the response pattern turns into the selected situation. The results of responses to objects are not formed by the condition but are chosen by the brain after going through the process of situation modification. The choice of the situation itself concerns the strength of attention and cognitive change that is understood as a complex system that does not merely respond to stimulants as it is but is processed through cognitive mechanisms. The following is a description of the procrastination work pattern [13].

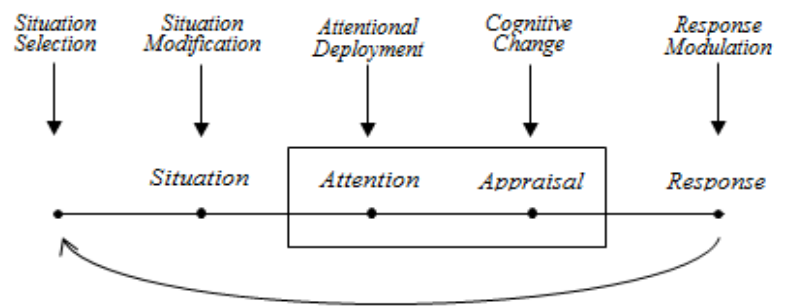

Figure 3. The Description of Procrastination Work Patterns

The explanation above shows the strong relationship between procrastination and the academic work system. The academic work system is a system that is structured, systematic, and method in which each unit is linked exponentially. The exponential nature makes the academic 
work process by deploying all intelligence components into it, including self. Academic procrastination is a failure to do an academic task within the desired time frame or postpone doing a job until the very last moment [15]. The impact that occurs due to academic procrastination is often not a particular concern for some people who experience procrastination [16].

One of the academic work is writing skill. Writing skill is essentially a skill to pour ideas or opinions into writing. Writing is a productive activity of a language that is considered the most complex aspect of communication skill compared to other communication skills such as speaking. It is called the most complex because, in this skill, the results can be reflected, analyzed, considered, and revised to be used by the communication messages they contain.

Writing is an activity carried out by exploring the thoughts and feelings for all subjects, choosing something to write, and choosing how to write so that people who read the results can understand easily [17]. In line with that, writing is an activity of arranging graphic symbols into words and then going into sentences based on grammatical rules and the ability to generalize knowledge into written language that is easily digested by readers
[18]. The difficulty faced in writing lies in the generalization and management of ideas and transferring ideas into written symbols. Students must have other skills to support abilities, especially planning and organizing ideas or other required skills such as spelling, punctuation, vocabulary, and grammar. The level of difficulty in writing activities is higher if other language skills are low [19].

\subsection{Research Objective and Framework}

The purpose of this study was to identify the effects of the academic procrastination on the scientific guidance process. The following figure 4 is the research framework to describe this study.

\subsection{Research Question}

This research aimed to examine academic writing guidance process of postgraduate students at UIN Alauddin Makassar. In other words, this study was going to answer the following question: How did the pattern of academic procrastination affect the scientific guidance process in UIN Alauddin Makassar?

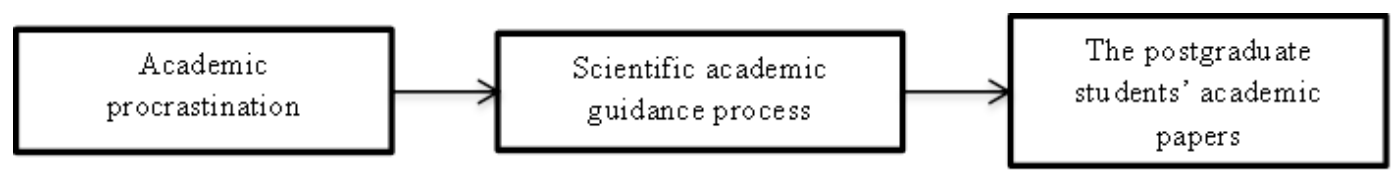

Figure 4. Research Framework 


\section{Methodology}

\subsection{Research Design}

This study used quantitative and qualitative methods. Mixing these methods is due to the nature of the data to be drawn from the phenomenon. Some were obtained quantitatively, and some were acquired qualitatively [20]. The design of this study used a responsive evaluation model developed by Robert Stake. It covers three main phases; antecedents, transactions, and outcomes.

\subsection{Research Sample}

The sample of this research was the postgraduate students of UIN Alauddin Makassar. The researchers used random sampling to choose 16 Postgraduate students as the respondents, aiming to gain real data from the research source.

\subsection{Research Instruments}

The research instruments used were questionnaire and interview. The questionnaire is based on general aspects of procrastination, a design standardized by Tuckman. It covered three aspects; (1) tendency to delay/crastinus, (2) the tendency to choose the atmosphere in the completion of the task, and (3) the tendency to blame others for failure. These three elements were developed into 35 items of procrastination statements with answer choices using the Five-Point of Likert Scale; always, often, sometimes, rarely, and never. At the same time, semi structured-interview was used to gain additional data related to the students' writing academic guidance process.

\subsection{Data Analysis}

Descriptive statistics were employed to analyze the quantitative data such as mean score, frequency, and percentage. The descriptive qualitative data were analyzed into three phases; assessing input data (antecedents), evaluating object work procedures (transactions), and synchronizing results (outcomes). Thus, responsive criteria were based on how effective the guidance process for writing scientific papers was applied in the Postgraduate Program at UIN Alauddin Makassar [21].

\section{Findings}

This current research aimed to identify the effects of academic procrastination pattern on the scientific guidance process. The following table shows the obtained data from the postgraduate students in answering the research question.
Table 1. General Description of Academic Procrastination to the Postgraduate Students' Scientific Papers

\begin{tabular}{|c|c|c|}
\hline No. & Description & Score \\
\hline 1. & Total respondents & 16 \\
\hline 2. & Score range & 20 \\
\hline 3. & Min. score & 122 \\
\hline 4. & Max. score & 142 \\
\hline 5. & Mean & 130 \\
\hline 6. & Standard deviation & 7.0 \\
\hline 7. & Total & 2080 \\
\hline
\end{tabular}

Table 1 reveals the general score of the postgraduate students' academic procrastination. The score range of 16 respondents was 20. The highest and the lowest score were 142 and 122, respectively. The mean score was 130 with 7.0 of standard deviation. Also, the academic procrastination items divided into three aspects. Based on data analysis, those aspects were presented in the following table.

Table 2. The aspect of Tendency to Delay (crastinus)

\begin{tabular}{|c|c|c|c|c|}
\hline No. & Interval & Frequency & Median & Percentage \\
\hline 1. & $45-49$ & 2 & 47 & 12.5 \\
\hline 2. & $50-54$ & 3 & 52 & 18.75 \\
\hline 3. & $55-59$ & 5 & 57 & 31.25 \\
\hline 4. & $60-64$ & 6 & 62 & 37.5 \\
\hline
\end{tabular}

Table 3. The aspect of the Tendency to Choose the Atmosphere in the Completion of the Task

\begin{tabular}{|c|c|c|c|c|}
\hline No. & Interval & Frequency & Median & Percentage \\
\hline 1. & $23-27$ & 7 & 25 & 43.75 \\
\hline 2. & $28-32$ & 9 & 30 & 56.25 \\
\hline
\end{tabular}

Table 4. The aspect of the Tendency to Blame Others for Failure

\begin{tabular}{|c|c|c|c|c|}
\hline No. & Interval & Frequency & Median & Percentage \\
\hline 1. & $36-40$ & 2 & 38 & 12.5 \\
\hline 2. & $41-45$ & 7 & 43 & 43.75 \\
\hline 3. & $46-50$ & 7 & 48 & 43.75 \\
\hline
\end{tabular}

Table 2, 3, and 4 present the aspect distribution scores of the postgraduate students' academic procrastination. All tables illustrate the interval, frequency, median, and percentage of those three aspects. The highest percentage was 56.25 of the tendency to choose the atmosphere to complete the task, while the lowest was 12.5 of both tendency to delay and tendency to blame others for failure. Therefore, the academic procrastination indicated quite high, which meant it was insufficient to be effective guidance to produce good academic works.

The respondents' answers to the interview varied. They have their own perception related to academic procrastination. It can be understood that they have different experiences during the writing thesis or 
dissertation guidance process. Several students mentioned the following statements:

"The guideline confuses me. Some parts have a general explanation that makes me put off doing my works." (Student B, Male, 25 years old)

"I am late to begin my writing because I cannot distinguish the guidelines for writing articles, papers, or theses. It takes time for me to read it.” (Student D, Female, 24 years old)

"The supervisors have busy schedule so that the academic guidance is taking a long time.” (Student A, Female, 26 years old)

"I have to do my job and write thesis at the same time. I need a good time to start my scientific academic paper." (Student F, Male. 26 years old).

\section{Discussion}

The guidance of the students' academic work by lecturers was one of the fundamental factors in higher education institutions' qualifications. As shown in various studies, the supervising intensity also influenced the students' academic works' final results. This study noted several facts that students' academic guidance at Postgraduate was not running optimally. Some critical points were relevant with several factors: (1) Guidelines for writing scientific papers were general so that the types of students' academic works were not formulated; (2) The formal flow of guidance was not perfectly regulated, and (3) The postgraduate students' procrastination was relatively high with the use of scientific writing guidelines and the quality of students' academic papers.

Guidelines for guiding scientific papers at UIN Alauddin Makassar have been compiled into a Guideline for Writing Scientific Paper, which was first published by Alauddin Press in 2013 and revised in 2016 with a total of 129 pages. This last edition was quite comprehensive because it had accommodated almost the entire needs of scientific writing by all academicians at UIN Alauddin Makassar. Its comprehensive nature made the handbook a general guide to writing and reporting scientific work in its various types: papers, theses, dissertations, and other scientific articles. Because of this generality, the distinction between types of tasks was not detailed. Some substantive parts, such as research plan material, did not explain what the design content was. Problem formulation, for example, if examined carefully, the description of this section only solved the problem definition and mechanism for formulating the problem. In no way did it describe how to formulate the problem relevant to the type of research. It did not discuss the technical formulation problem even though the accuracy of the problem's formulation determined the other formulations' accuracy.

Another example was the discussion of an operational definition. This section did not explain what should be in the operational formulation because it only describes the definition, function, and placement in the design composition. The announcement of section discussion, as in other parts, could be assumed as the cause of many errors in determining the focus of studies in students' scientific works.

The formal flow of the operational guidance did not describe the procedural break down until depositing the manuscript. In the handbook, this explanation only reached the research preparation or planning stage. This guideline did not explain further procedures after obtaining guidance from a supervisor unless referred to as an official sign of the study's start. The study showed that many students immediately research obtaining approval in the proposal exam without previously consulting the devices to be implemented in the field. Ideally, before the students conduct research, they firstly ensured the validity and efficacy of the instruments that they would use. That was, consultation and test instruments were part of the "official mark of research" that requires the intensity of guidance and testing.

The above mechanism was suspected to be the reason for students' preparation to begin the research in a structured manner that could not be done. Some thesis and dissertation works were found not to have sufficient theoretical formulation to be developed into instruments to obtain the data. Some works must be overhauled in other observations after taking the feasibility test because the results were not based on valid and reliable measuring instruments. In terms of supervising efficiency, it was clear that reshuffle was not necessary if the instrument's evaluation process was first carried out.

In line with the research findings, it was suspected that in addition to the Guidelines for Writing Scientific Papers: Factors of lecturer procrastination also influence articles, thesis, dissertation, and research reports which had weaknesses of guidance, the inefficiency of scientific guidance in the Postgraduate of UIN Alauddin Makassar in reading the work student academics. It is also suspected that lecturers tended not to read students' manuscripts, so student works' writing value was relatively low. Inversely, the proportional to the written composition value, the lecturer was thought only to ensure that the writing components must be in the structure of the whole essay, including the systematic sequence.

\section{Conclusion}

The academic guidance process of Postgraduate students did not run optimally because of several factors as follows; (1) The postgraduate students' weak differentiation of thesis/dissertation writing techniques with other scientific work types was suspected to affect the quality of students' academic writing results; (2) The imperfect formal flow of guidance causes the intensity of 
thesis/dissertation guidance after the qualification examination proposal stops until it enters the results qualification examination stage; (3) The students' academic procrastination on academic guidance process was moderate so that the quality of students' thesis/dissertation report results was relatively low. This study recommends that Postgraduate UIN Alauddin Makassar should compile guidelines for the writing of scientific papers that are applied exclusively to the needs of the guidance and reporting of scientific papers.

\section{REFERENCES}

[1] J. S. Wrench, V. P. Richmond, and J. Gorham, Communication, Affect, and Learning in the Classroom. San Francisco: Tapestry Press, 2009.

[2] K. O’Hagan, Competence in Social Work Practice, a Practical Guide for Students and Professionals. Philadelphia: Jessica Kingsley Publisher, 2007.

[3] W. Knaus, The Procrastination Workbook: Your Personalized Program for Breaking Free from the Patterns. New York: Harbinger Publications Inc, 2002.

[4] J. Ferrari and D. Tice, Procrastination as a Selfhandicap for Men and Women: A Task-Voidance Strategy in a laboratory Setting. J. Res. Pers., 2000.

[5] N. Fiore, Overcoming Procrastination: Practice the Now Habit and Guilt-Free Play. New York: MJF Books, 1989.

[6] G. Schraw, T. Watkinds, and L. Olafson, "Doing the Things We Do: A Grounded Theory of Academic Procrastination," J. Educ. Psychol., vol. 99, no. 1, 2007.

[7] R. Boice, Overcoming Procrastination: Practice the Now Habit and Guilt-Free Play. Westport: Praeger Publisher, 1996.

[8] W. J. Livesley, Handbook Personality Disorders: Theory,
Research and Treatment. New York: Guilford Press, 2001.

[9] Mierrina, "Pengaruh Pelatihan Shalat terhadap Prokrastinasi dan stres Kerja Pekerja Muslim dan Muslimah,” J. Penelit. Psikol., vol. 2, no. 1, 2011.

[10] A. Abuhmaid and M. Abood, “The Impact of Flipped Learning on Procrastination and Students' Attitudes toward It,” Univers. J. Educ. Res., vol. 8, no. 2, pp. 566-573, 2020, doi: 10.13189/ujer.2020.080228.

[11] L. J. Solomon and E. D. Rothblum, “Academic Procrastination: Frequency and Cognitive-Behavioral Correlates,” J. Couns.

[12] S. Suryabrata, Psikologi Pendidikan. Jakarta: Raja Grafindo Persada, 2002.

[13] K. McRae, K. N. Ochner, and J. J. Gross, The Reason in Passion: A Social Cognitive Neuroscience Approach to Emotion Regulation. New York: The Guilford Press, 2011.

[14] D. Groome et al., An Introduction to Cognitive Psychology: Processes and Disorders. London: Taylor \& Francis, 2005.

[15] C. A. Wolters, "Understanding Procrastination from a Selfregulated Learning Perspective,” J. Educ. Psychol., 2003.

[16] S. Muyana, "Prokrastinasi Akademik Dikalangan Mahasiswa Program Studi Bimbingan dan Konseling,” $J$. Bimbing. dan Konseling, vol. 8, no. 1, pp. 45-52, 2018, doi: 10.25273/counsellia.v8i1.1868.

[17] J. McCrimmon, Writing with Purpose. Boston: Houghton Mifflin Company, 1984.

[18] E. Gould, R. Di Yanni, and W. Smith, The Act of Writing. Toronto: Random House, 1989.

[19] J. C. Richard and W. A. Renandya, Methodology in Language Teaching: An Antology of Current Practice. Cambridge: Cambridge University Press, 2002.

[20] D. Ary et al., Introduction to Research in Education. Belmont: Wadsworth, 2010.

[21] R. Stake, Responsive Evaluation. Washington DC: Eric Clearinghouse, 1972. 